\title{
HUMAN RIGHTS WATCH BACKGROUNDER LANDMINE USE IN AFGHANISTAN
}

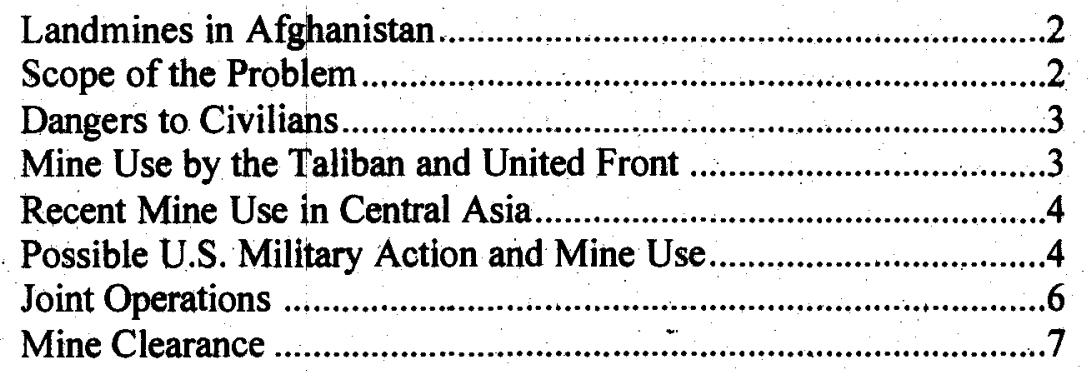

October 2001 


\section{Landmines in Afghanistan}

Afghanistan is one of the most heavily mined countries in the world. Landmines pose an ever-present danger to civilians now attempting to flee the country or areas of potential conflict. If United States forces engage in ground combat in Afghanistan, they will face a serious threat from antipersonnel and antitank landmines laid over the course of the past twenty-plus years. The use of mines in Afghanistan and surrounding countries has increased in the past year, with the United Front (formerly the Northern Alliance) continuing to use mines inside Afghanistan, and the forces of Russia (in Tajikistan), Uzbekistan, and Kyrgyzstan laying mines on borders. The armed conflict in Afghanistan could precip itate the planting of new landmines by the Taliban, the United Front, and the U.S.-led coalition. Even if no significant new landmines are laid, efforts to demine the country will undoubtedly be deferred for the duration of the armed conflict. The grim reality of the mine situation in Afghanistan can only be exacerbated by the current crisis.

\section{Scope of the Problem ${ }^{1}$}

Landmines have been planted indiscriminately over most of the country. Grazing areas, agricultural land, irrigation systems, residential areas, and roads and footpaths, in both urban and rural areas, are contaminated. ${ }^{2}$ For years, mines have been a major obstacle to repatriation, relief, rehabilitation, and development activities.

Landmines and other unexploded battlefield detritus, commonly known as unexploded ordnance (UXO), contaminate at least 724 million square meters of land in Afghanistan. Only two of Afghanistan's twenty-nine provinces are believed to be free of landmines. The most heavily mined provinces are Herat and Kandahar. Kandahar is the stronghold of the Taliban and a likely focal point for armed conflict. Other heavily infested provinces include Farah. Paktia, Kabul, Zabul, Ghazni, and Paktika. These provinces border on Pakistan and Iran, the most common destinations for the tens of thousands trying to leave the country. Even the capital, Kabul, is mine-affected.

The full extent of the landmine problem in Afghanistan is yet to be determined. In addition to continued laying of mines, previously.mined areas are still being discovered at a rate of twelve to fourteen million square meters per year.

It is generally estimated that millions of mines are scattered throughout the country. ${ }^{3}$ While virtually all combatants in Afghanistan in recent decades are thought to have used mines,

\footnotetext{
' Except where noted, the following information is extracted from: International Campaign to Ban Landmines (ICBL). Landmine Monitor Report 200). pp. 497-518. Human Rights Watch is the lead organization responsible for publishing this annual survey of the global landmine situation. The complete report can be accessed on line at www.icbl.org/lm/2001.

2 The data from a socio-economic impact study conducted by the Afghan Mine Clearance Planning Agency and published in December 1999 revealed that mine and UXO affected land consisted of 61 percent grazing land. 26 percent agricultural land. 7 percent roads. 4 percent residential areas, and 1 percent irrigation systems.

In 1998 a U.S. Department of State survey of the global landmine crisis reduced earlier estimates of ten million mines to a range of five to seven million mines. U.S. Department of State. Bureau of Political-Military Affairs.
} 
most were laid by Soviet and pro-Soviet Afghan government forces from 1979-1992. At least fifty different types of mines have been identified in Afghanistan of Belgian, Chinese, exCzechoslovakian, Iranian, Italian, Pakistani, Singaporean, ex-USSR, United Kingdom, exYugoslavian, and Zimbabwean manufacture. ${ }^{4}$ The United States provided landmines to mujahidin fighters as part of U.S. covert assistance in the 1980s.

\section{Dangers to Civilians}

Landmines already kill or maim more civilians in Afghanistan than in any other country. Afghan civilians face injury or death on a daily basis because of mines and unexploded ordnance. In the year 2000 , there were on average about eighty-eight recorded mine/UXO casualties per month. ${ }^{5}$ It is believed that the actual number of new mine victims could be 50 percent to 100 percent greater, taking into account those deaths and injuries that go unreported.

This appalling civilian toll will in all likelihood grow significantly with the rapid and chaotic movement into unfamiliar territory of civilians fearing U.S. airstrikes and military operations by the various Afghan forces. Others, facing food shortages and other hardships, will seek refuge in areas where they hope to gain access to humanitarian assistance. The most heavily mined provinces are those bordering Pakistan and Iran, which are also the major destinations for those attempting to flee. Many are also attempting to reach Tajikistan, but in the past year Russian forces based in Tajikistan have mined the Tajik-Afghan border. The presence of mines has often been cited as a major factor deterring refugees from returning to Afghanistan; tragically, landmines will now claim victims among those attempting to leave the country to avoid conflict.

\section{Mine Use by the Taliban and United Front}

The Taliban claims to have stopped the use of antipersonnel mines in 1998, declaring it un-Islamic and punishable by death. ${ }^{6}$ There has been no credible evidence of use by Taliban forces since 1998, though some allegations have emerged in recent weeks.

The opposition United Front continued to use antipersonnel mines in 1999 and $2000 .^{7}$ In early May 2001, the leader of the United Front, Burhanuddin Rabbani, denied any recent use of

Office of Humanitarian Demining Programs, Hidden Killers, September 1998, p. A-1. Some knowledgeable observers believe there are no more than one million mines. These statistics continue to be the subject of debate; no one can be confident of an accurate estimate. More importantly, the real impact of landmines in A fghanistan is determined by the amount of land denied productive use, not the number of mines.

${ }^{4}$ ICBL, Landmine Monitor Report 1999, p. 436, provides a detailed list of mine types; see also. Human Rights Watch, "Crisis of Impunity: The Role of Pakistan, Russia, and Iran in Fueling the Civil War in Afghanistan," $A$ Human Rights Watch Short Report, vol. 13, no. 3 (C), July 2001, p. 23 and p. 37.

${ }^{5}$ This was a sharp decline from an average of 130 recorded casualties per month in 1999 and an estimated 600 or more per month in 1993 . These decreases can largely be attributed to successful mine survey, marking, clearance, and awareness programs.

${ }^{6}$ ICBL, Landmine Monitor Report 2001, p. 497, citing interview on April 4, 2001.

${ }^{7}$ Details are provided in ICBL, Landmine Monitor Report 1999 and 2000.

Human Rights Watch Backgrounder: Landmines in Afghanistan

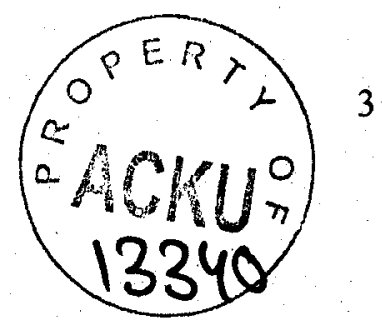


antipersonnel mines by United Front forces in a meeting with Landmine Monitor researchers. ${ }^{8}$ However, that same month, Ambassador Peter Tejler of Sweden told reporters on the return of a European Union mission from Afghanistan, "Northern Alliance [United Front] leaders admitted that they lay landmines eve n now.",

\section{Recent Mine Use in Central Asia}

The Landmine Monitor Report 2001 documented a number of cases of new instances of antipersonnel mine use, or serious allegations of new use, in Central Asia. These include:

- Russian forces based in Tajikistan, beginning in late 2000, have laid antipersonnel mines inside Tajikistan on the Tajik-A fghan border. The International Campaign to Ban Landmines (ICBL) has criticized this action, noting that it could put Tajikistan in violation of the 1997 Mine Ban Treaty, to which it is a State Party.

- Uzbekistan has laid antipersonnel mines on its borders with Tajikistan (in 2000) and Kyrgyzstan (beginning in late 1999) and reports of mine use continued to be received in mid-2001. Both the Tajik and Kyrgyz governments have accused Uzbekistan of emplacing mines across the border in their territory.

- Kyrgyz forces reportedly mined the border with Tajikistan in summer and fall 2000, then subsequently cleared the mines.

These new deployments have resulted in increased civilian mine casualties in these border areas.

\section{Possible U.S. Military Action and Mine Use}

The United States is not among the 142 countries that have signed, ratified, or acceded to the 1997 Mine Ban Treaty prohibiting any possession or use of antipersonnel mines. Current policy was set forth in Presidential Decision Directive (PDD) 64 issued on June 23, 1998, which sets the goal of joining the Mine Ban Treaty by 2006 if the Pentagon has successfully fielded alternatives to antipersonnel mines. ${ }^{10}$ In early June 2001, the Bush Administration began a review of landmine policy, the status of which remains unclear in the wake of the attacks of September 11.

On October 10, the third night of the military action by the United States and United Kingdom against Taliban positions and facilities, B-52 and B-1 bombers reportedly dropped "area munitions," including CBU-89 Gators. " The CBU-89 Gator is a mixed-mine system

\footnotetext{
${ }^{8}$ ICBL. Landmine Monitor Report 200/. p. 498. citing Landmine Monitor Researchers interview with Professor Burhanuddin Rabbani, president of the Islamic State of Afghanistan. the government ousted in 1996, of which the United Front is the military arm. Faizabad. Afghanistan. May 3.2001.

"Anti-Taliban alliance admits receiving foreign military support." Deutsche Presse-Agentur. May 24. 2001.

${ }^{10}$ President Clinton committed the United States in 1998 to cease using antipersonnel mines. except those contained in "mixed systems" with antivehicle mines. everywhere in the world except Korea by 2003. By 2006. if alternatives have been identified and fielded, the United States will eease use of all antipersonnel mines and will join the Mine Ban Treaty (Ottawa Convention).

${ }^{11}$ Michael R. Gordon and Steven Lee Myers. "Taliban's Troops Hit as Allies Plan for Commando Raids." The New York Times. October 11.2001.
} 
containing both antipersonnel and antivehicle mines. ${ }^{12}$ If confirmed, this would mark the first time the U.S. is known to have used antipersonnel mines since the Gulf War one decade ago.

The CBU-89 Gator Mine System is a 1,000-pound cluster munition containing twentytwo antipersonnel mines and seventy-two antitank mines. The antipersonnel mines are activated by tripwires that will explode by the presence of a civilian or combatant. While the mines are equipped with self-destruct and self-neutralizing features to make them "short-lived," nations negotiating the 1997 Mine Ban Treaty rejected U.S. demands that these mine systems be exempted from the treaty. The use of self-destructing and self-neutralising antipersonnel mines will not prevent new mine victims and the clearance task will be just as time-consuming and costly, perhaps even more so.

Reasons for this include:

- Self-destruct mechanisms are not 100 percent reliable. The Landmine Protocol of the 1980 Convention on Conventional Weapons (to which the United States is a State Party) allows a 10 percent failure rate.

- These mines are scattered (or remotely-delivered) from the air with little precision, there is no way to accurately mark or map or fence the mined areas to keep civilians out.

- Civilians in these mined areas face the danger not only of accidentally detonating mines that have failed to self-destruct, but of coming upon hundreds of those mines randomly self-destructing at unknown times.

- These mines still deny land to civilians. Because they are remotely-delivered, they are found on the surface of the ground, not buried. If they are aware the area is mined, civilians will not enter it, knowing that the visible mines may still be dangerous and fearing the presence, in many places, of mines that have been overgrown or otherwise obscured.

- Mines that have failed to self-destruct but have self-deactivated will have to be treated by deminers as live mines that may potentially explode. Thus, an area that has unexploded mines in it will have to be cleared with the same care as any other minefield. The time and cost will be similar.

- The clearance job may be made more difficult by the large numbers of mines present (given the propensity to use thousands at a time in remote-delivery systems). U.S. Gator mines were still being cleared from Kuwait several years after Operation Desert Storm.

If the U.S. attempts to undertake a ground operation in Afghanistan, not only will it face formidable challenges posed by Afghanistan's uncleared, unmarked, and unmapped minefields but it could encounter areas riddled with unexploded Gator mines as it did in the Gulf War, when the U.S. Air Force employed 1,105 CBU-89s. According to declassified Pentagon documents, U.S. troops stormed Iraq so rapidly in 1991 that they penetrated their own "live" minefields. ${ }^{13}$

\footnotetext{
${ }^{12}$ For technical information on the CBU-89, see the Military Analysis Network of the Federation of American Scientists http://www.fas.org/man/dod-101/sys/dumb/cbu-89.htm

13 "In its Own words: The U.S. Army and Antipersonnel Mines in the Korean and Vietnam Wars." Human Rights Watch and l'ietmam Veterans of America Foundation Short Report. vol. 9. no. 3 (G). July 1997. pp. 11-12.
} 
In 1999 U.S. Army engineer units reportedly deployed to Albania with antipersonnel mines and their delivery systems (MOPMS and Volcano mixed mine systems) as part of Task Force Hawk to support operations in Kosovo. ${ }^{14}$ According to the source of the information, most of the U.S. Army units deployed from bases in Germany. At the time of this deployment, Albania was a signatory to the Mine Ban Treaty and Germany was a State Party to the treaty.

The U.S. has approximately 300,000 aerially-delivered Gator mines in stock. Other antipersonnel mines available to U.S. forces include artillery-delivered ADAM mines (about 9.5 million), and MOPMS $(9,000)$ and Volcano $(100,000)$ mines that are used by Army engineer troops. Some of these mines are stored in foreign locations, including Norway, Japan, Germany, Saudi Arabia, Qatar, Diego Garcia (United Kingdom), Kuwait, Oman, Greece, Turkey, and South Korea. These mine systems, which (except for ADAM) contain a mix of antipersonnel and antivehicle mines, are the type that are designed to self-destruct or self-deactivate after a set period; they still leave an unacceptable risk for civilians and are banned under the 1997 Mine Ban Treaty.

There has been much speculation, but little concrete information, about what type of ground operations, if any, the U.S. might undertake in Afghanistan. There have been reports that U.S. Special Operations Forces (SOF) are already present in the region and possibly in the country. In general (though Human Rights Watch has no direct knowledge of this circumstance), SOF have at their disposal one type of antipersonnel mine: the Pursuit Deterrent Munition (PDM). According to the U.S. Army's Field Manual on mine warfare, "The PDM is used as a deterrent by speciatoperations forces (SOF) and in operations where units may be pursued by an enemy force. $" 15$ The PDM is a hand-emplaced, wedge shaped mine which, when armed, deploys six-meter long tripwires. If the tripwires are disturbed, the mine bounds to a height of 2.5 meters and explodes. The PDM is designed to self-destruct four hours after arming and contains an anti-disturbance switch. ${ }^{16}$ Special Operations Forces like Green Berets, Rangers, SEALs, and others can be expected to possess PDM; the U.S. has more than 16,000 in stock. ${ }^{17}$

\section{Joint Operations}

Human Rights Watch and the ICBL have repeatedly raised concerns about the possible participation of States Parties to the Mine Ban Treaty in joint military operations with non-States Parties that use antipersonnel landmines. There is concern about the consistency of such operations with the treaty's article I obligation for a State Party "never under any

\footnotetext{
${ }^{14}$ Major Scott C. Johnson, "Strategic Mobility, the Force Projection Army, and the Ottawa Landmine Treaty: Can the Army Get There?" A student monograph submitted to fultill the requirements of the School of Advanced Military Studies. U.S. Army Command and General Staff College, February 15.2001. This paper by a student in a military school does not represent the position or vicw of the U.S. Government. Department of Defense. or U.S. Army. However, the author. in footnote 94 (page 48), states: "Matt Pasvogel, interview by author, 09 January 2001. Captain Pasvogel was an engineer company commander who deployed with Task Force Hawk. His unit deployed with both MOPMS and Volcano mine dispensing equipment and mixed self-destructing AP/AT mines. Munitions that were not employed during the mission. but were available in Albania for use if the need did arise."

${ }^{15}$ Department of the Army. Field Manual (FM) 20-32. Mine/Countermine Operations. May 29. 1998. Chapter 4.

${ }^{16}$ Ibid.. Chapter 4 and Appendix B.

17 Landmine Monitor Report 1999. p. 330.
} 
circumstances... [t]o assist, encourage or induce, in any way, anyone to engage in any activity prohibited to a State Party under this Convention." In particular, the question has been raised as to what "assist" means in the treaty's article 1. A number of governments have interpreted this to mean "active" or "direct" assistance in actual laying of mines, and not other types of assistance in joint operations, such as provision of fuel or security. ${ }^{18}$

All members of NATO except the U.S., Turkey, and Greece are States Parties to the Mine Ban Treaty. ${ }^{19}$ The ICBL has called on those nations to inform the United States that use of antipersonnel mines in NATO operations is unacceptable. In response to the September 11 attacks, NATO has for the first time invoked article 5 of its treaty, stating that an attack on one member is an attack on all.

The planes which deployed the CBU-89 Gators in Afghanistan on October 10 reportedly took off from the island ofDiego Garcia, a territory of the United Kingdom, which is a State Party to the Mine Ban Treaty. If this action were to be determined to constitute assistance on the part of the United Kingdom, the U.K. would be in violation of the treaty.

Likewise, if U.S. forces are deployed in Tajikistan, that government, which is a State Party, has an obligation to insist that no U.S. antipersonnel mines be stockpiled in, transited through, or deployed from Tajikistan. Tajikistan has a similar obligation with respect to Russian forces operating on its soil.

\section{Mine Clearance}

Apparently, all mine clearance activities in Afghanistan have been suspended since September 12, 2001, according to the United Nations Mine Action Program for Afghanistan (MAPA). On the second night of the military action by the United States and United Kingdom against Taliban positions and facilities, on October 9, four employees of the nongovernmental organization Afghan Technical Consultants (ATC) died during U.S. airstrikes over Kabul. ATC is the oldest and largest mine action NGO in Afghanistan. ${ }^{20}$

\footnotetext{
${ }^{18}$ ICBL, Landmine Monitor Report 2001, pp. 17-21. See also: Human Rights Watch, "Joint Operations and the Mine Ban Treaty - Memorandum for Delegates," May 11, 200.1 on line at: www.hrw.org/campaigns/mines/2001/memo0511.htm

${ }^{19}$ Greece is a signatory. The foreign ministers of Greece and Turkey announced in April 2001 that the two countries would simultaneously join the Mine Ban Treaty in the near future as a confidence building measure.

${ }^{20}$ ATC has 1,299 employees. It mainly operates in the central and eastern regions of the country, with its head office in Peshawar (Pakistan) and offices in Gardez; Kandahar and Jalalabad. In 2000, ATC operated with twentyone manual clearance teams, six battle area clearance teams, four mechanical mine clearance teams and four Explosive Ordnance Disposal (EOD) teams and cleared more than 4.2 million square meters of mine contaminated area and approximately 20 million square meters of former battle area contaminated by UXO. During these clearance operations 2,748 antipersonnel mines, forty-three antitank mines and 66,406 UXO were destroyed.
}

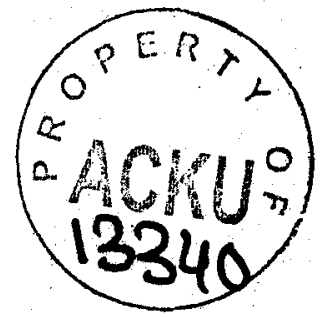

